ST ATE OF ILLINOIS

DEPARTMENT OF REGISTRATION AND EDUCATION

DIVISION OF THE

NATURAL HISTORY SURVEY

STEPHEN A. FORBES, Chef

\begin{tabular}{lll} 
Vol. XVII. BULLETIN & Article III. \\
\hline
\end{tabular}

\title{
An Epidemic of Leeches on Fishes in Rock River
}

BY

\author{
DAVID H. THOMPSON
}

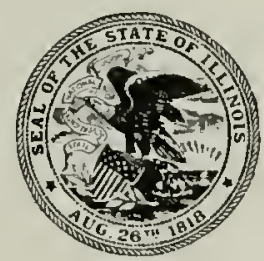

PRINTED BY AUTHORITY OF THE STATE OF ILLINOIS

URBANA, ILLINOIS

November, 1927 
STATE OF ILLINOIS

DEPARTMENT OF REGISTRATION AND EDUCATION

A. M. SHeltox, Director

\section{BOARD OF}

\section{NATURAL RESOURCES AND CONSERVATION}

A. M. Sheltox, Chairman

William Trelease, Biology Henri C. Cowles, Forestry Edson S. Bastin, Geology William A. NoYes, Chemistry
Jonn W. Alvorb, Engineering Charles M. Tilompson, Representing the President of the University of Illinois

THE NATURAL HISTORY SURVEY DIVISION

Stephen A. Forbes. Chief

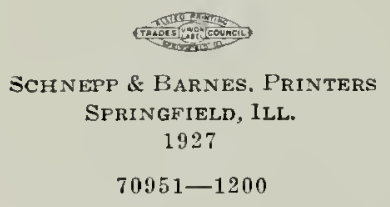




\title{
AN EPIDEMIC OF LEECHES ON FISHES IN ROCK RIVER
}

\author{
DAVID H. THOMPSON
}

$I^{\prime}$

I the course of field work in aquatic biology on Rock River it was noticed in the winter of $1995-199$ (i that almost every red-mouth butialo (Ictiobus cyprinclla Cuv. \& Val.) was heavily infested with the leech, Piscicola punctata V'errill.* This leech had not been taken during the two preceling years of almost continuous work on this river. which included the collecting of hundreds of samples of the bottom famn and the handling of many thousands of red-muth louffalo at all seasons of the year. Noreover, fishermen at many points on the river reported that no such infestation had occurred in the last half-century and that the only time they had ever seen any such leeches on the butfalo was about ten years ago when a few were noticel during some early spring fishing. The first appearance of Piscicola punctuta in epidemic proportions was on Feloruary ?.5, 19:6, ahout four miles above Rockford. The river's winter covering of ice having "gome out" of most of the channel the previous day, the remaining ice was moved off an eldy, and a seine haul was made which included, among a nmmber of other fishes, tis redmouth huffalo weighing one to two pounds each, 3s of which were infested with this leech. The number of leeches on each of the infested fishes ranged from 1 or:? up to 50 or more with an average of alont 20 .

The point of attack was most often in the axils of the fins and about the anus. where the cuticle is relatively thin : however, clusters of leeches were often found attached to other parts of the body. especially in places where the cuticle had been broken by injurjes. I nissing scale or a cut usually offered a place of attachment for several leeches. Those which had jenetrated the cuticle or hard found an opening in it were wsually well filled with blood and mucus; others contained mucus only or were quite elinty.

\section{Extext OF TIE EPINEMIC}

During the remainder of Felsuary and throughent March, leeches were found on the red-mouth butfalo in nuch the same numbers and proportions as just described for the first haul. Sieine lauls made in this period over a :0-mile stretch of Rock River in the vicinity of Rockford netted :s:31 red-mouth buff̈alo, averaging abuut : pounds in weight. The leeches were so numerous that the lottom of a boat in which fishermen harl handled a few hundred pounds of fishes was almost completely corered with them. 
"Thin" fishes usually bore more leeches than "fat" ones. Whether the leeches made the fishes thin, or whether thin fishes were predisposed to leeches, is uncertain. The fishermen picked off the leeches before the fishes were sold on the retail market. When the leeches were removed, the place of attachment was raw and bleeding and was surrounded by a halo of inflamed flesh. Fishes infested with lecches were less desirable for market, partly because the wounds and blood-shot flesh injured their appearance and partly because the mere thought of leeches was repulsive to buyers. Many thin, infested buffalo were thrown back by the fishermen while sorting the marketable fishes out of the seine.

At this same time fishermen seining farther down the river near Oregon also found the red-mouth buffalo very heavily infested with leeches. Those taken in the channel of the river were reported to have about the same number of leeches as described for the Rockford region, but those taken in sloughs and backwaters were much more heavily infested, individual fishes often bearing more than a hundred leeches.

Fishermen at other points on Rock River found leeches on the buffalo during the same winter, but there is no evidence that the epiclenic extended into other streams of the State. One commercial fisherman, of many years experience in catching buffalo at all seasons of the year on the lower Illinois River near Meredosia and on the Mississippi River near Savanna, reportecl that he had never seen leeches in any considerable numbers on the fishes. The most that he had ever seen were on some red-mouthed buffalo taken on the Mississippi during sone early spring fishing five years ago, but they numbered only two or three to a fish. Fishermen on the Wabash River at Lafayette, Indiana, saw no such epidemic.

During the epidemic on the red-mouth buffalo, other fishes were occasionally found infested with small numbers of the same leech. The snuall-mouth buffalo (Ictiobus bubalus) was thus attacked, most often in the axils of the fins and about the antus. The common red-horse (Moxostoma aurcolum), which is somewhat more abundant in Rock River than the small-mouth buffalo, was affected even less; on it, no leeches were seen which were filled with blood, althotigh many were well filled with mucus. The mongrel buffalo, the European carp, the common river carp (or quillback), and the common (or black) sucker were found with small numbers of leeches on them. It is possible that the leeches attached themselves to these other fishes after having been dislodged from red-mouth buffalo in the seine.

\section{Seasonal Habits of the Leeches}

The epidemic began while the river was covered with ice and ended soon after the ice had gone and the water temperature had risen a few degrees above freezing. There were no leeches on any of the 1481 redmouth buffalo taken by the writer during November, 1925, in the same locality. Fishing was continued by the commercial fishermen in the same locality until late in December, when the river froze over for the winter, but no leeches were noticed. It seems probable, therefore, that the red- 
mouth buffalo became infested with the leeches sometime during the montl of January.

At the end of March, a decline in the number of leeches was evident. This was preceded by a sharp rise in the water temperature (see Table I). Since the river was covered with ice, water temperatures between $0^{\circ} \mathrm{C}$.

T.IBI, I

ROCK RHER WATER TEAPERATERE* (C.) ARONE ROCKFORI DAM, 1926

\begin{tabular}{|c|c|c|c|c|}
\hline $\begin{array}{l}\text { Day of } \\
\text { month }\end{array}$ & February & March & April & May \\
\hline $\begin{array}{r}1 \\
2 \\
3 \\
4 \\
5 \\
6 \\
7 \\
8 \\
9 \\
10 \\
11 \\
12 \\
13 \\
14 \\
15 \\
16 \\
17 \\
18 \\
19 \\
20 \\
21 \\
22 \\
23 \\
24 \\
25 \\
26 \\
27 \\
25 \\
29 \\
30\end{array}$ & $\begin{array}{l}0.1 \\
0.15 \\
-0.05 \\
0.05 \\
0.1 \\
0.1 \\
0.45 \\
0.6 \\
1.2\end{array}$ & $\begin{array}{l}1.1 \\
2.85 \\
\\
2.3 \\
2.9 \\
2.55 \\
3.25 \\
6.65 \\
6.2 \\
4.55\end{array}$ & $\begin{array}{l}1.3 \\
1.3 \\
1.35 \\
4.4 \\
3.45 \\
4.75 \\
7.0\end{array}$ & $\begin{array}{l}13.55 \\
14.65 \\
15.05\end{array}$ \\
\hline 31 & & 0.05 & & \\
\hline
\end{tabular}

* Each temperature is an average of two readings:

(a) I foot below surface, and (b) 1 foot abose bottom.

and $1^{\circ} \mathrm{C}$. nunst have obtained throughout January and February. On March 18 , a rise in temperature began which reached a maximum of $6.0^{\circ}$ C. on March ?t. During the last days of March the temperature fell again to freezing and then rose steadily throngh the first three weeks of April. reaching a maximum for the month of $1.5 .5^{\circ} \mathrm{C}$. on April ?2. The number of leeches declined through the first half of April, until on April 
1 i only 2 leeches were seen on 51 red-mouth buffalo, and the last leech was seen on a buffalo on April 30, although several hundred red-mouth buffalo were examined for then during the summer.

An effort was made to find out what becane of these leeches after they left the fishes. The bottom of the river was sampled in many places where the leech-infesterl buffalo had been abundant. A number of them were found on April 29 among the fanna living on the vegetation in Long Slough above Rockford. There, on clumps of Elodea, they appeared empty and quite active, in contrast to their well-filled and sluggish condition when found on fishes. Earlier in the spring the fishermen had taken many leech-infested buffalo from this slough. Late in April in the same place, red-nnouth buffalo were seen with fungous infections in wounds evidently made by the leeches.

Since the leeches had not been found until late in February, it is not known exactly when they first attacked the buffalo, there having been no fishing since December, when the river had frozen over. It was with considerable interest. therefore, that the buffalo were examined in the fall and early winter of 1926 . Leeches first reappeared on then at Rockford and Sterling on Novenber 30, which was after the temperature of the water had dropped to less than $1^{\circ} \mathrm{C}$. and the more quiet parts of the river had frozen over. They were also taken by the writer on December 5 and on following days, near Sterling and Oregon. from buffalo in seine hatuls made where the ice had been moved away.

The leeches at this tine were very small and active, translucent and apparently empty. They measured 8-10 $\mathrm{mm}$. in length, as contrasted with those measuring $20-30$ mm. which were taken the preceding spring. They grew rapidly and reached adult size during Jantuary. While young. they apparently fed on mucus alone, but as they became larger they were seen to be filled with blood as well as mucus. The number found during this winter was only a small fraction of the number found the preceding winter. Counts made at Sterling in December showed that about onefourth of the buffalo were infested, and that the average number of leeches per fish was 2 . Just as in the preceding spring. they left their hosts as soon as the water temperature had risen a few degrees above freezing. The river remained at or near the freezing point and the leeches remained on the fishes up to March 19 , when a three-clay rain melted the ice and raised the temperature of the water. On March 2:, when the temperature was $40^{\circ} \mathrm{F}$. $\left(4.4^{\circ} \mathrm{C}\right.$. $)$, very few leeches were left on the fishes, and a few days later there were none.

Since that time, a very thorough search has been made for Piscicola functata, including nore than 100 collections taken in all sorts of situations in the river and adjacent waters, but not a single individual has been found.

Moore ${ }^{1}$ sums up what is known of the habits of this leech, as follows: "This is our commonest fresh water fish leech. It is common in the ponds

${ }^{1}$ Monre, J. Percy. Classification of the Leeches of Minnesota. Geological and Nitural History Survey of Minnesota, Zoological Series, No. V, Part III, p. 105 (1912.) 
and lakes of the morthern states and the Mississippi Valley and is especially abundant along the Ohio shore of Lake Erie. It lives upon the exterior of the body of various species of small fishes, feeding upon the mucus which covers the surface as well as upon their blood. It appears to be in no way injurious to its hosts. Many examples may also he found living annons water plants, 10 the stems of which there is good reason to jelieve its stalked cocoons are attached."

\section{DESCRIRTION}

The following description, which is hased in all particulars on examination of specinens talien on the red mouth buffalo in Rock River, includes the external characteristics only, and in a few items, where there is no disagreenent, uses language earlier employed by Noore.

Usual size 15 to $25 \mathrm{~mm}$.. but extensible to a greater length; greatest diameter 2 or $3 \mathrm{~mm}$. A narrow neck-like constriction embracing the first few somites behind the anterior sucker; the posterior two-thirds much flattened when the animal is contracted. The posterior sucker when expanded is wider than the widest portion of the body, and normally three or four times the diameter of the anterior sucker. One pair of eyes, with conspicuous bar-like pigment cups, which are place obliquely, converging anteriorly, and which in length are each equal to more than a fourth of the breadth of the anterior sucker. Behind these are two smaller pigment spots, also somewhat bar-like, and easily mistaken for a second pair of eyes.

Living specimens had a translucent greenish ground-color, as describerl by Verrill, when containing little or no blood; both the upper and lower surfaces of both body and suckers were densely covered nearly everywhere with minute black specks, irregularly arranged. Along each side are eight or more sub-equally spaced pale spots wbich are partly visible from above, and which are connected with each other lengthwise by narrower pale areas, forming a continuous pale lateral stripe for most of the animal's length. The pale dorsal stripe found by Verrill is only faintly developed or wbolly absent in a majority of the specimens which were closely examined. When filled with blood the greenish groundcolor is largely submergerl, except on the two suckers, and the general appearance is speckled brownisli.

\section{COLOR T'ARIAKT}

During this epidenic on the red-month butfalo, a different-appearing leech, provisionally identified as a color variant of $P$. punctata, was found on the small-nouth black bass and the wall-eyed pilie. It is smaller than the luffalo leecl and is dark brown instead of an iridescent pale green. It occurred almost exchusively on the head of its host; fifty were once found about the month and branchial region of a small-moutl black bass weighing $1 \frac{1}{2}$ pounds. These leeches noved about rather actively and were closely applied to the host throughout their lengh. while the buftalo leech was usually seen hanging by its catudal stcker. the remainder of the boly dangling in the water. These smaller brown leeches apparently fed upon nucus alone, since none were seen filled with blood and no injuries 
were found on the host which could be attributed to them. They curl up tightly when killed in formalin while the buffalo leech dies straight or but slightly bent. These leeches disappeared from the smill-mouth black bass at the same time as did those on the buffalo, and they reappeared in reduced numbers in the following winter.

\section{Other Species of Piscicola}

Another leech of this genus, $P$. milncri Verrill, is reported by Milner ${ }^{2}$ to have been taken in large numbers on fishes in Lake Michigan: "The Ichthyobdellan, a leech of three-fourths of an inch long, grayish white in color, with brown tesselated markings, was seen in great numbers in the month of April, while the fishermen were lifting their nets from about fifty fathoms some fifteen miles out from Kenosha, Wis. They covered the nets and fishes of all species, and fell in such numbers on the deck that it became slippery, and an old coat was thrown down for the man who was lifting the gang to sand upon. They were very tenacious of life, living for a long time on the deck, and for several days in the bilge-water of the fish-boats. They were in such numbers that it was diffcult to decide whether they had a preference for any species, and were found filled with blood both in the gills and while attached to the body, though it was difficult to inagine that they could fill themselves with blood from the epidermal sheath of the scales. They were thought to be most numerous on the white-fishes, as they were in greater numbers on them than on the trout, the lawyer, or the cisco, the only other fishes taken. A prevailing but mistaken opinion in the vicinity was that the white-fish fed upon the leech. Dr. Hoy's investigations disproved the notion, and all exanninations of stomach-contents confimed this fact."

Dr. F. B. Adamstone is quoted by Moore ${ }^{3}$ in regard to $P$. milncri in Lake Nipigon as follows: "this leech (piscicola) is found by hundreds on whitefish, and the decks of the tugs are strewn with them when the nets are lifted." This species is parasitic on whitefish throughout the year, although it is also found free-living (presumably in summer) on floating vegetation and in the more shallow waters. In view of the fact that $P$. punctata infests the red-mouth buffalo only when the water is cold, it may be of some significance that the whitefish spends the warmer months in the deep waters of the lakes where the temperature is close to $4^{\circ} \mathrm{C}$.

The European species, P. gcomctra L., is a common pest and well known to fish culturists. According to Plehn, ${ }^{4}$ it not only seriously dan-

${ }^{2}$ Milner, James W. Report on the Fisheries of the Great Lakes; the Results of 1nquiries Prosecuted in 1871 and 1872. Rept. U. S. Comm. Fish \& Fisheries, Part II, for 1872 and 1873 , p. 64 .

${ }^{3}$ Moore, J. Percy. The Leeches (Hirurlinea) of Lake Nipigon. University of Toronto Studies, Biological Series, No. 25: Publications of the Ontario Fisheries Research Laboratory, XXIT-XXVI, page is. (1924.)

Plehn, Marianne. Praktikum der Fischkrankheiten. Handbuch der Binnenfischerei Mitteleuropas. Band I. Page 339. (1924.) 
ages its hosts but also transmits the blood parasite Trypanoplasma cyprini. This leech apparently attacks the fishes at all seasons and does not have its parasitic habit restricted to a narrow temperature range.

No evidence of any special seasonal relationship to the host has been found in the literature on other species of this genus uccurring in various parts of the world.

\section{EFFect ox Fisil lieLD}

The epidemic of Piscicola punctata apprecially affected the fish yield of Rock River for the spring of 1926 , and the possibility of its continuing to do so should be considered, since the red-mouth buffalo is second only to the carp in commercial importance. While other species of this genuts regularly appear in large numbers on fishes in other waters, this is the only known instance where this species assunied the proportions of a pest with which it would be necessary to reclion. Within the memory of the oldest fishermen of Rock River, it has never been seen except in small numbers and at long intervals. During the winter of 19?6-192:, it was present in only about one-tenth of the numbers found the previous winter. There were no unusual conclitions known to be prevalent in Rock River during these years which could obviously predispose to such an epidemic. Considering these things, it seems likely that Piscicola punctata will not continue to occur in sufficient numbers to affect the fish yield and that it may again be relegated to the rarer species of the river fauna.

\section{ACKNOWLEDGMENTS}

I am indebted to Mr. R. E. Richardson, biologist, and to Mr. H. C. Oesterling, editor, both of the Survey staff, for aid in the preparation of this paper, and to Mr. F. D. Hunt, zoological assistant, and others for aid in the collection of material and information. 